ДВНЗ “Тернопільський державний медичний університет

імені І. Я. Горбачевського МОЗ України”

\title{
ШЛЯХИ ОПТИМІЗАЦІї ПІДГОТОВКИ ЛІКАРІВ-ІНТЕРНІВ ДО ЛІЦЕНЗІЙНОГО ІНТЕГРОВАНОГО ІСПИТУ “КРОК З”
}

\author{
G. V. Stoikevych, O. I. Lebid, K. M. Duda \\ I. Horbachevsky Ternopil State Medical University \\ METHODS OF OPTIMIZATION OF TRAINING OF INTERNS TO THE \\ LICENSED INTEGRATED EXAM KROK 3
}

\begin{abstract}
Мета роботи - вдосконалення знань та підготовка лікарів-інтернів другого року навчання до складання ліцензійно-інтегрованого іспиту “Крок 3” зі спеціальності “Стоматологія”.

Основна частина. У статті проаналізовано результати проведення низки тестових контролів у рамках підготовки інтернів другого року навчання до складання ліцензійного іспиту “Крок 3”. Отримані висновки дозволяють створити рекомендації щодо поліпшення результативності в процесі підготовки та збереження знань до моменту складання ліцензійного іспиту.

Описано позитивну динаміку результатів написання лікарями-інтернами ректорських контрольних робіт у рамках підготовки до ліцензійного інтегрованого іспиту “Крок 3. Стоматологія”.

Поєднання теоретичної підготовки, розбору клінічних ситуаційних задач та комп’ютерного онлайн-тестування дає можливість закріпити знання до моменту написання іспиту.

Висновок. Чітка організація навчального процесу під час підготовки лікарів-інтернів та контроль якості складання проміжних іспитів на базі кафедри та ректорських контрольних робіт дасть можливість покращити клінічне мислення, поглибити теоретичні знання, і як результат приведе до збільшення відсоткового співвідношення здачі ліцензійного іспиту “Крок 3. Стоматологія”.
\end{abstract}

Ключові слова: Крок 3; стоматологія; навчальний процес; тестування; післядипломна освіта.

The aim of the work - improvement of knowledge and training of interns in the second year of study before the licensing-integrated exam Krok-3 on the specialty of Dentistry.

The main body. The article analyzes the results of a series of test controls in the preparation of interns in the second year of study before the Krok-3 licensed exam. The obtained conclusions allow creating recommendations for improvement of the effectiveness in the process of preparation and preservation of knowledge until the time of the licensing exam.

The article describes the positive dynamics of the results of writing internship-doctoral examinations for the Krok-3 licensed integrated exam. The combination of theoretical training, the analysis of clinical situational problems and computer online testing, allows you to consolidate your knowledge until the exam is written.

Conclusion. Organization of the educational process during interns training and quality control of the preparation of intermediate examinations on the basis of the department and rector's control will enable to improve clinical thinking, deepen theoretical knowledge and, as a result, will increase the percentage of Krok-3 licensed exam.

Key words: Krok 3; dentistry; educational process; testing; postgraduate education.

Вступ. Крок 3 - це іспит з професійно-орієнтованих дисциплін, які відповідають програмі підготовки спеціалістів у сфері медицини. Він $є$ обов'язковою складовою частиною державної атестації для присвоєння освітньо-кваліфікаційної категорії “Лікар-стоматолог” [5].

Ліцензійний іспит є найбільш показовим критерієм якості освітнього процесу в інтернатурі. Він відображає кінцевий результат навчання, характеризує ступінь відповідності знань лікарів-інтернів

( Г. В. Стойкевич, О. І. Лебідь, К. М. Дуда вимогам державних стандартів [4]. Досвід попередніх ліцензійних іспитів “Крок 3” свідчить про те, що значний відсоток лікарів-інтернів не завжди долає заліковий рубіж через недостатні знання, розгубленість, стресову нестійкість. Щоб мінімізувати ці причини, підготовка лікарів-інтернів різних спеціальностей, зокрема стоматологів, до ліцензійного іспиту “Крок 3” є базовим завданням сучасної післядипломної освіти $[1,2]$. Одним із методів підготовки є написання лікарями-інтернами ректорських контрольних робіт і подальший аналіз 
їх результатів. Регулярне проведення ректорської контрольної для лікарів-інтернів стоматологічного факультету є важливою складовою у підготовці їх до написання ліцензійного іспиту “Крок 3” [3].

Мета роботи - оцінити ефективність підготовки лікарів-інтернів до ліцензійного інтегрованого іспиту “Крок 3” зі спеціальності “Стоматологія” Навчально-наукового інституту післядипломної освіти ДВНЗ “Тернопільський державний медичний університет імені І. Я. Горбачевського МОЗ України”.

Основна частина. Для покращення результатів написання ліцензійного іспиту “Крок 3” та організації навчального процесу наказом від 28.12.2016 p. № 656 по Тернопільському державному медичному університету видано розпорядження провести ректорський контроль знань з “Крок 3” серед лікарів-інтернів другого року навчання зі спеціальності “Стоматологія”.

Навчально-науковим інститутом післядипломної освіти, відділом моніторингу якості освіти складено графік проведення ректорських контрольних робіт, які проходили в лекційних аудиторіях університету, під контролем відповідальних викладачів кафедри стоматології даного інституту та спеціально створеної комісії центру тестування університету.

Для оптимізації підготовки лікарів-інтернів до складання ліцензійного іспиту “Крок 3” на кафедрі стоматології післядипломної освіти було розроблено буклети, які включали в себе тестові завдання 3 бази центру тестування з 2009 по 2017 рік включно. Було створено 18 варіантів завдань, які включали в себе питання з різних розділів стоматології. Кожного дня, на семінарських заняттях, проводилося обговорення тестових завдань, розбір клінічних задач, які входили в базу підготовки до “Крок 3”. Інтерни самостійно в комп’ютерному класі проходили онлайн-тестування. Наприкінці кожного

\section{Список літератури}

1. Досвід впровадження пілотного “КРОК-2” з хірургічних хвороб у навчальний процес студентів 6 курсу Одеського національного медичного університету / В. В. Грубнік, Ю. М. Кошель, В. В. Міщенко, О. І. Ткаченко // Здобутки клінічної і експериментальної медицини. - 2016. - № 2. - С. 44-45.

2. Принципы подготовки врачей-интернов разных специальностей по циклу “Неотложные состояния” / В. В. Ехалов, В. И. Слива, Д. М. Станин [и др.] // Медицина неотложных состояний. - 2011. - № 4 (35). С. $126-128$.

3. Кулаєць В. М. Підготовка лікарів-інтернів до ліцензійного інтегрованого іспиту “КРОK-3. Загальна тижня проводився тестовий контроль, який давав змогу проаналізувати рівень засвоєння вивченого матеріалу і виділити інтернів, з якими потрібно працювати додатково і посиленіше.

Прохідний відсоток ректорського іспиту становив 75,0 \%. Згідно зі створеним графіком, тестування проводилося двічі. Лікарів-інтернів, які за результатами ректорських контрольних давали низький відсоток, формували в групи ризику і проводили з ними додаткові заняття.

Проаналізувавши результати проведених ректорських контрольних робіт з “Крок 3” серед лікарівінтернів другого року навчання зі спеціальності “Стоматологія” на базі ТДМУ, середній результат склав 78 \%. За результатами першого ректорського контролю 75 \% бар'єр не досягли 44,5 \% лікарівінтернів, за результатами другого - 78,3 \%. Цей відсоток відображав ризик незадовільних результатів під час написання ліцензійного інтегрованого іспиту “Крок 3”, який відбувся в листопаді 2017 р.

Якщо порівнювати результати написання ліцензійного інтегрованого іспиту “Крок 3” з попередніми роками, то спостерігалася позитивна динаміка. Так, у 2015 р. відсоток лікарів-інтернів, які не перетнули відсотковий бар’єр 70,5, склав 37 \%, в 2016 р. - 24 \%, а в 2017 р. він склав 12 \%, що підняло ВНЗ на четверту сходинку серед ВНЗ, лікаріінтерни-стоматологи яких складали “Крок 3”.

Висновок. Чітка організація навчального процесу під час підготовки лікарів-інтернів на базі кафедри стоматології Навчально-наукового інституту післядипломної освіти ТДМУ та контроль якості складання проміжних іспитів та ректорських контрольних робіт дасть можливість покращити клінічне мислення, поглибити теоретичні знання, і як результат приведе до збільшення відсоткового співвідношення здачі ліцензійного іспиту “Крок З. Стоматологія”.

лікарська підготовка” / В. М. Кулаєць // Буковинський медичний вісник. - 2015. - Т. 19, № 1 (73). - С. 261-262. 4. Навчальний план та програма спеціалізації (інтернатури) випускників вищих медичних закладів освіти III-IV рівнів акредитації за фахом “Стоматологія” / М. М. Рожко, В. Ф. Куцевляк. - Полтава, 2013. - С. 47. 5. Стимулювання індивідуальної творчості у підготовці лікарів-інтернів за фахом “Загальна практика сімейна медицина” до ліцензійного іспиту “КРОК-3” / О. Ю. Сорокіна, О. М. Клігуненко, В. В. Єхалов [та ін.] // Біль, знеболювання та інтенсивна терапія. - 2013. № 3 (64). - C. 13-14. 


\section{References}

1. Hrubnyk, V.V., Koshel, Yu.M., Mishchenko, V.V., \& Tkachenko, O.I. (2016). Dosvid vprovadzhennia pilotnoho “KROK-2” z khirurhichnykh khvorob u navchalnyi protses studentiv 6 kursu Odeskoho natsionalnoho medychnoho universytetu [The experience of implementing the pilot "KROK-2" from surgical diseases into the educational process of students of the 6th year of the Odessa National Medical University]. Zdobutky klinichnoi i eksperymentalnoi medytsyny - Achievements of Clinical and Experimental Medicine, 2, 44-45 [in Ukrainian].

2. Yegalov, V.V., Sliva, V.I., Stanin, D.M., Lyashchenko, O.V., \& Kligunenko, Ye.N. (2011). Printsipy podgotovki vracheyinternov raznykh spetsialnostey po tsiklu "Neotlozhnyye sostoyaniya” universytetu [The principles of training interns of different specialties in the cycle «Emergency states»]. Meditsina neotlozhnykh sostoyaniy - Emergency Medicine, 4 (35), 126-128 [in Russian].

3. Kulaiets, V.M. Pidhotovka likariv-interniv do litsenziinoho intehrovanoho ispytu "KROK-3. Zahalna likarska pidhotovka” [Preparation of interns for a license integrated exam of KROK-3. General Doctor's Training].
Bukovynskyi medychnyi visnyk - Bukovyna Medical Bulletin, 19, 1 (73), 261-262 [in Ukrainian].

4. Rozhko, M.M., \& Kutsevliak, V.F. (2013). Navchalnyi plan ta prohrama spetsializatsii (internatury) vypusknykiv vyshchykh medychnykh zakladiv osvity III-IV rivniv akrydetatsii za fakhom "Stomatolohiia" [Curriculum and program of specialization (internship) of graduates of higher medical establishments of education of III-IV levels of accreditation in the specialty of Dentistry]. Poltava [in Ukrainian].

5. Sorokin, O.Yu., Klihunenko, O.M., Yehalov, V.V., Kravets, O.V., \& Stanin, D.M. (2013). Stymuliuvannia indyvidualnoi tvorchosti u pidhotovtsi likariv-interniv za fakhom "zahalna praktyka-simeina medytsyna" do litsenziinoho ispytu "KROK-3” [Stimulation of individual creativity in the preparation of interns in the specialty of General Practice - Family Medicine for the licensed exam KROK-3]. Bil, zneboliuvannia ta intensyvna terapiia Pain, Anesthesia and Intensive Therapy, 2 (64), 13-14 [in Ukrainian]. 